\title{
A CYTOLOGICAL STUDY OF ANTERIOR HORN CELLS ISOLATED FROM HUMAN SPINAL CORD ${ }^{1}$
}

\author{
LIANG-WEI CHU ${ }^{2}$ \\ Department of Epidemiology and Virus Laboratory, School of Public Health, \\ University of Michigan, Ann Arbor \\ TWENTY-EIGHT FIGURES
}

Knowledge concerning the structure of the neuron is based primarily on the study of fixed and stained tissue sections. The opinion has often been expressed that some of the cell structures revealed by elaborate methods may be artefacts of fixation and impregnation. This skepticism has stimulated attempts to study the nerve cell in the living state. For this purpose, two types of study are available, namely, observations on neurons in tissue cultures and on those isolated from fresh tissues.

Studies of nervous tissues in culture have been largely concerned with the outgrowth of neurites and the proliferation of macrophages. The neuron itself has less often been the object of study chiefly because embryonic nerve cells show little migration from tissue explants to permit unhindered observation. Nevertheless, notable results have been obtained from the recent studies of Hogue ('47, '50), Murray and Stout ('47), and Pomerat and associates (Pomerat et al., '50; Costero and Pomerat, '51), using fetal as well as adult human material. However, neurons in tissue cultures show

1 Aided in part by a grant from the National Foundation for Paralysis, Inc.

Supported by a fellowship grant from the Program of Emergency Aid to Chinese Scholars, Department of State, Washington, D. C. 
profound adaptive changes and thus differ in many morphological features from neurons in the intact organism.

The other method of approach involves mechanical separation of nerve cells from fresh tissues. Owing to the complexity of the nervous tissue, it is difficult to avoid injury to the nerve cell and its processes during separation. Nevertheless, observations on these isolated cells have furnished valuable information relating to various cell structures in the fresh condition as compared with those after fixation and staining. The studies of Held (1895), Marinesco ('11), Mott ('12), de Moulin ('23), Wiemann ('25), Chinn ('35) and de Rényi ('31), using conventional, darkfield, ultraviolet and polarizing light microscopy as well as micrurgical technique, may be cited.

Previous investigators probably did little more than teasing the tissue to reveal the cell-body of the neuron for microscopic observation. It is, however, more desirable to be able to isolate a fairly large number of nerve cells with the processes more or less intact and completely free from nonnervous elements. Besides lending themselves more readily to modern methods of microscopy, such isolated cells may be used for the study of the physical properties and the chemical composition of the neuron; of the direct action, on the neuroplasm, of various chemicals, toxins, enzymes, viruses, etc.; and, if methods are available for maintenance of these cells in physiological condition, of the metabolism of the isolated neuron.

An effort has been made to isolate the motor nerve cells from the anterior horn of the human spinal cord. The technique consists in shaking the gray matter in a physiological salt solution to free the nerve cells from the supportive elements and then separating them from each other by the method of differential flotation. In this report, observations on the isolated neurons in the fresh condition with ordinary light and phase contrast microscopy and on their reactions to certain stains and chemicals will be presented. 


\section{MATERIALS AND METHODS}

Segments of the lumbar portion of the spinal cord were removed during autopsy in the Pathology Department of the University of Michigan Hospital. The autopsy material consisted chiefly of hospital patients who died from various causes, their age ranging from new-born to over 80 years. There was usually an interval of several hours between the arrival of the body at the morgue and the performance of the autopsy. Cell isolation experiments were made immediately after obtaining the cord tissue or the tissue was kept in the refrigerator temporarily when the experiment had to be delayed.

After removing the dura, the cord was washed with saline solution and split along the midline into lateral halves with a pointed scalpel. The posterior quadrant was cut away and the gray matter of the anterior quadrant was dissected out. The anterior gray column thus obtained was cut into small pieces and transferred to a test-tube. After adding about $5 \mathrm{ml}$ of a physiological salt solution (Hanks' or Simms' balanced salt solution or simply $0.85 \%$ sodium chloride solution) and 10-15 small glass beads, the tube was gently shaken by hand for 5 or more minutes until a fine suspension was obtained. In this crude suspension were completely separated neurons, detached axons and dendrites, fragments of myelin sheath, neuroglia and capillaries. At times, especially when there was evidence of autolysis in the cord tissue, the nerve cells in the suspension were found to be much fragmented. However, in many instances the neurons were intact with most of their processes still attached.

For the separation of neurons from non-nervous matter in the gray matter suspension, advantage was taken of the former's slightly greater density. The method used was to sediment the nerve cells down a column of fluid having a specific gravity of about 1.06. A mixture of equal volumes of $20 \%$ sucrose and normal horse serum was usually employed. Solution of plasma albumin or gum acacia of the same specific gravity could also be used, except that with their use many 
of the cells tended to stick to the wall of the tube after centrifugation. The diluted gray matter suspension ( 4 or $5 \mathrm{ml}$ ) was layered on top of an equal volume of sucrose-serum mixture in a test-tube. After centrifugation at 1,500 r.p.m. for 5 minutes, the nerve cells, together with a small amount of other material, settled to the bottom of the tube, but most of the non-nervous matter remained above the sucrose-serum mixture. The procedure was repeated three or 4 times in order to get a purer suspension of nerve cells. Although over nine-tenths of the non-nervous matter could be removed in this way, a cell suspension entirely free of other material could not be obtained even when the procedure was repeated many times. Finally the nerve cells were suspended in Hanks' or Simms' solution with or without the addition of serumultrafiltrate (Hanks and Wallace, '49; Simms and Sanders, '42).

The cells could now be examined under the microscope by placing a drop of the suspension on a slide and covering it with a cover-glass. In order to study the reaction of the nerve cell to various stains, a drop of dilute aqueous dye solution was mixed with a drop of cell suspension on the slide before microscopical examination.

\section{OBSERVATIONS}

\section{Nerve cells}

General characteristics. Two types of nerve cells were usually isolated by the procedure described above. Besides the large multipolar neurons (figs, 1-7, 12-15), there were many small ones (figs. 8-11), most of which have a slender, spindleshaped cell-body, with dendrites coming off each end and an axon from one side of the cell-body. These small neurons were probably from the dorsal or lateral horn, part of which might be dissected out together with the anterior gray matter. The observations described in the following account were made mainly on the multipolar anterior horn cells. The shape of these isolated cells as observed under the microscope was 
quite similar to that seen in sections of fixed material, because it represented simply a view of the cell with its plastic cell-body and processes spreading out on the surface of a slide. Practically all anterior horn cells were observed to have one diameter somewhat longer than the others as described by Kraus and Weil ('26) and occasionally anterior horn cells with definitely elongated cell-body were encountered.

Plasma membrane. The neuron appeared to have a limiting membrane of fair tensile strength. When the cover-glass was pressed downward, the cell-body swelled up to form a round mass, but resumed its original shape when the pressure was released. However, no definite structure of this cell membrane was discernible by phase microscopy or with the the aid of staining. It may consist of just a surface layer of specially oriented lipid and protein molecules as suggested by Chinn ('35).

Ground substance. The ground substance in which the nucleus and various granules are imbedded appears to be homogeneous, without fibrillar or reticular structure. It seemed to be a viscid, gelatinous substance, because no Brownian movement of the cytoplasmic granules was observed and because, when the cell was broken, both the ground substance and the granules remained with the broken pieces instead of flowing out into the fluid medium. The ground substance was stained readily with acid dyes, like eosin and erythrosin, but not at all with basic dyes.

Cytoplasmic granules. When freshly isolated anterior horn cells were stained with a dilute solution $(1: 10,000)$ of methylene blue, toluidine blue or thionin, the Nissl bodies appeared sharply stained against the unstained ground substance. The appearance and distribution of these cytoplasmic bodies were similar to those observed in fixed sections. Without the aid of stains, the Nissl bodies in the cell-body could not be clearly seen by ordinary light microscopy, though those in the dendrites could be fairly well made out as well-defined particles slightly darker than their surroundings. Under the phase 
contrast microscope, the entire cell appeared to be filled with granules of various sizes (figs. 7, 15). Besides the Nissl bodies, there was a great number of small granules. The latter were also basophilic, though somewhat less so than the Nissl bodies. All the granules appeared to be discrete bodies, with no indication that the smaller ones joined together to form bridges connecting the larger ones as described by Wiemann ('25). The Nissl bodies appeared to have a well-defined contour and a homogeneous structure and not formed by the aggregation of smaller granules as suggested by Held (1897) and Bensley and Gersh ('33). Neurofibrils were not seen in the cell-body or the processes. Structures indicative of Golgi bodies were not observed.

The process of staining these cytoplasmic granules by basic dyes could be followed under the microscope. Immediately after a drop of dye solution was mixed with a drop of the cell suspension, the dye was taken up by the granules selectively and progressively. Under no circumstance did the entire cell appear at first diffusely stained and then show Nissl granules when the dye condensed in certain places as reported by de Moulin ('23).

The Nissl bodies were also stained deeply red with methyl green-pyronin (each 1:5,000). With methyl green alone, the Nissl substance was entirely unstained. Some of the fine granules were stained by Janus green B (1:5,000). Judging from their size and shape, such granules were probably mitochondria. All cytoplasmic granules as well as the nucleolus were deeply stained by neutral red $(1: 10,000)$, but the ground substance was also slightly colored.

After isolation, the nerve cells could be kept in Hanks' or Simms' solution or simply in normal saline in the refrigerator with no apparent alteration in appearance for two or three weeks or even longer. However, the cytoplasmic granules lost their basophilic property gradually on storage at low temperature $\left(4^{\circ} \mathrm{C}\right.$.). The loss of basophilia was much hastened if the cells were kept at $37^{\circ} \mathrm{C}$. Incubation with ribo- 
nuclease $^{3}(1 \mathrm{mg} / \mathrm{ml})$ brought about complete loss of basophilia in one-half hour, while desoxyribonuclease ${ }^{3}(1 \mathrm{mg} / \mathrm{ml})$ did not produce a similar effect in 4 hours. The loss of basophilia, whether caused by storage or enzyme, was not followed by observable disintegration of the Nissl bodies.

The isolated nerve cell could withstand $1 / 5 \mathrm{~N} \mathrm{HCl}$ without alteration in appearance but the cytoplasmic granules promptly lost their property on exposure to acid. When placed in $1 / 5 \mathrm{~N} \mathrm{NaOH}$, the cell gradually became swollen and finally completely disintegrated in 10-15 minutes. In a somewhat less alkaline medium, the cell was not visibly affected but the Nissl bodies were stained reddish purple instead of blue with methylene blue or toluidine blue. However, the blue color could be restored when acid was added to neutralize the alkalinity of the medium.

Occasionally, anterior horn cells that were obviously chromatolytic were isolated from the autopsy material (figs. 14, 15). Such cells presented, besides disappearance of the Nissl bodies, all the other stigmata of chromatolysis as observed in stained sections, such as cellular swelling, eccentric position of the nucleus, thickening of the nuclear membrane, etc. Phase microscopy showed that many fine granules were still present in the cytoplasm of such cells, though the large ones had disappeared. These fine granules were also slightly basophilic. It has not been possible to produce the phenomenon of chromatolysis in the isolated cells with normal Nissl bodies by means of enzymes or chemicals.

Lipochrome pigment. A brownish yellow pigment was always present in the cytoplasm of anterior horn cells isolated from an adult individual. It occurred as discrete granules collected into one or two clusters beside the nucleus (figs. 2-4, 12-15, 21). Some pigment granules could often be found in the dendrites and occasionally a large dendritic trunk was filled with them. Both axon and axon hillock were entirely free from these pigment granules.

\footnotetext{
${ }^{3}$ Crystalline ribonuclease and desoxyribonuclease purchased from Worthington Biochemical Laboratory, Freehold, New Jersey.
} 
Lipochrome pigment was absent from the spinal neurons of infants and very young children (figs. 1, 5-7, 20). In our series of over 500 cord specimens, the youngest person who first showed pigment in the anterior horn cells was a 6-year old child. The pigment was found in all individuals above that age and a fair amount was present in teen-aged individuals. In a rough way, the amount of pigment increases with the age of the individual.

The pigment granules have a characteristic shape and are fairly uniform in size (fig. 19). Though believed to contain lipids, they were only faintly stained by Sudan III or IV. They were not readily soluble in alcohol or acetone and resisted the action of $6 \mathrm{~N} \mathrm{NaOH}$ which readily dissolved the cytoplasm and nucleus. The latter finding can be utilized in the isolation of this pigment for direct chemical analysis.

Nucleus. The anterior horn cell has a large, vesicular nucleus with a prominent nucleolus. Often the nuclear membrane could not be seen in the fresh cell even under the phase microscope, probably because of the presence of the large cytoplasmic granules. When visible, the membrane sometimes appeared wrinkled. In chromatolytic neurons, the nuclear membrane became particularly evident not only because there were no more Nissl bodies to obstruct the view, but also due to the fact that there was frequently an accumulation of dense, basophilic material around the membrane. The nucleoplasm appeared to be clear and homogeneous, with a slight yellow tint, in the unstained cell. It also seemed to be made up of gelatinous material. Imbedded in the center of the nucleus is a large, spherical nucleolus, which stands out conspicuously in fresh cells, though the other parts of the nucleus are obscured by the cytoplasmic granules. The nucleolar spherules or satellites were, however, often difficult to see clearly in the isolated cells.

Both the nucleolus and the nuclear membrane were stained by basic dyes, but the nucleoplasm was not stained at all. The basophilic property of the nucleolus was much more slowly affected than that of the Nissl substance on storage. 
The nucleolus stained as deeply red as did the Nissl bodies with methyl green-pyronin, but with methyl green alone, it was also slightly colored green, whereas the Nissl bodies were completely unstained.

Dendrites. The anterior horn cell has three to 20 more dendrites coming off directly from the cell-body. The large dendritic trunk divides repeatedly into smaller and smaller branches. The total length of the dendritic processes from the edge of the cell-body to the tip of the terminal branch may measure as much as 10 times the diameter of the cellbody.

The surface of the dendrites is not smooth. Many cytoplasmic granules are found to be situated on the surface of the dendrite. This surface granulation seems to be a constant feature of the dendrites. Not infrequently the dendrites are marked by the presence of bud-like "excrescences" (figs. 16-18). Anterior horn cells isolated from certain individuals were found to have many such excrescences on the dendrites, although in other cases, few or none were demonstrated. Under the phase microscope, they appear to be dark particles studded on the surface of the dendrite. They are faintly stained by methylene blue or other basic dyes. It may well be that these excrescences are simply aggregates of the superficially situated cytoplasmic granules.

Axon. On account of the absence of Nissl substance and pigment granules, both the axon and the axon-hillock were readily identifiable even under ordinary light microscope without staining. For a short distance after its emergence from the hillock, the axon is without any covering. Just before the axon acquires its myelin sheath, there is a constriction in its diameter (figs. 20-22). It becomes slightly expanded again immediately after it enters the sheath, and then the diameter is maintained more or less constant for some distance. As could be imagined, most isolated nerve cells had their axons broken at the constricted portion. However, in cells with a considerable length of the axon still attached, this constric- 
tion has been observed without exception. The constriction seems to be exaggerated in the nerve cells of infants (fig. 20).

In the suspension of gray matter there were many segments of naked axons as well as gutted myelin sheaths. One gets the impression that the axon became detached from its sheath during shaking in saline. The segments of myelin sheath often showed bulgings at places, probably a result of shaking (fig. 23). ${ }^{4}$ The sheath wall appeared to be shiny and homogeneous, with no demonstrable structure.

The naked axon had a smooth surface and was fairly uniform in diameter, except that slight constrictions seemed to occur at intervals (fig. 24). These constrictions are probably related to the nodes of Ranvier believed to be present in the central nervous system - a subject of current interest (Allison and Feindel, '49; Hess and Young, '49; Bodian, '50). Under high magnification of the phase microscope, it was observed that there were in the axoplasm many fine granules or rodlets which were arranged roughly in rows but not evenly distributed (fig. 25). These granules or rodlets had smooth and sharply delineated contours and could be slightly stained by methylene blue or Janus green B. Besides these granules, no other structure could be observed by ordinary or phase microscopy with or without the aid of stains.

\section{Neuroglia}

Some intact neuroglia cells with their characteristic nuclei and processes were often seen in the suspension of gray matter. They were mainly protoplasmic astrocytes together with some oligodendroglias. Because of their lightness, most of them were separated from the nerve cells during the process of differential flotation. Figures 26-28 represent phase contrast photomicrographs of these glia cells. It will be noted that there is a thin clothing of cytoplasm containing the glio-

\footnotetext{
* Recently Fernández-Morán ('52) described the occurrence of fusiform-shaped enlargements of the myelin sheath fairly regularly spaced along the course of medium- and small-sized myelinated fibers isolated from the spinal cord of frogs and rats. These enlargements were not considered as artefacts.
} 
somes along the delicate processes of the astrocyte. The nuclei of the glia cells differ from those of nerve cells not only in structure but also in staining quality. The former are stained green, the latter red, with methyl green-pyronin.

\section{DISCUSSION}

Probably on account of its large size and relatively easy accessibility, the anterior horn cell (next to the spinal ganglion cell) has often been the object of study in experiments with nerve cells in the fresh state. Though it has been possible to tease out a few cells from the spinal cord for study, probably no one has succeeded in isolating completely a large number of intact neurons for observation and experiment as in the present work. Nervous tissues of a variety of amphibian and mammalian species have been used before, and, in one instance, human autopsy material has been used. We refer to Wiemann's study ('25) with ultraviolet light microscopy on the anterior horn cells isolated from the spinal cords of two fatal cases of general paresis shortly after death.

Like the structure of all other cells, the nerve cell consists of a nucleus and a variety of granules suspended in a ground substance enclosed in a limiting membrane. What is peculiar to the nerve cell is its gelatinous consistency; the protoplasm of other tissue cells isolated in a similar manner appear to have relatively low viscosity. This is in accord with all previous observations on fresh neurons, especially de Rényi's micro-dissection studies on the spinal motor cells of the frog ('31, '32). It is impossible to ascertain whether the nerve cell in the living organism is in this gel state or the gelation is incidental to the process of isolation. However, the study of Beams and King ('35) on the effect of ultracentrifugation of the spinal ganglion cells also points to high viscosity of their neuroplasm.

Confirming the findings of previous observers on the nerve cell in the fresh state, few of the cytoplasmic components are visible by ordinary light microscopy. This has given rise to the opinion held by some observers that certain cytoplasmic 
structures, especially the Nissl bodies, neurofibrils, and Golgi bodies, do not exist as such in the living neuron. (See a recent discussion by Beams et al., '52). The phase contrast microscope has revealed a variety of granules in the cytoplasm of the unfixed and unstained neuron, but neurofibrils and Golgi bodies have not been observed in the present study. The large cytoplasmic granules, because of their size, shape and distribution, undoubtedly correspond to the so-called Nissl bodies. The difficulty in observing these bodies by ordinary light microscopy is certainly due to lack of sufficient contrast and cannot, therefore, be considered as an evidence for their non-existence in the fresh neuron. Ralph ('52) recently reported the demonstration of Nissl substance in the nerve cell of the rat with phase microscopy without the aid of stains.

Our observations show that all the cytoplasmic granules are basophilic, though the small granules are much less so than the large ones. Since basophilia of the Nissl substance is attributed mainly to its ribonucleic acid (RNA) content (Gersh and Bodian, '43), it would follow that the smaller granules may also contain RNA though in small amounts. This is plausible because it is believed that nearly all RNA in the cytoplasm of the adult cell is associated with the cytoplasmic granules (Davidson, '47). That the nucleic acid in the Nissl substance is of the ribose type is further substantiated by its staining reaction to methyl green-pyronin and by the specific action of ribonuclease in the present observation on fresh cells, just as has been demonstrated in fixed sections before (Brachet, '40; Gersh and Bodian, '43; Hydén, '47). Though Einarson's results ('35) seemed to indicate that the Nissl bodies are partially stained by methyl green, we have not found this to be the case. Unna and Gans ('14) also stated that purified methyl green did not stain the Nissl bodies. However, the nucleolus has been shown to be slightly stained by methyl green, which is undoubtedly due to the existence of a thin shell of desoxyribonucleic acid (DNA) around the periphery of the nucleolus (Hydén, '47). 
The fact that the eytoplasmic granules lose their basophilic property more rapidly than does the nucleus seems to indicate that the RNA present in the cell becomes depolymerized and probably degraded on storage much more rapidly than does DNA. A similar phenomenon has been reported with mouse ascites tumor cells (Klein, Kuruck and Klein, '50).

Phase microscopy has indicated that the cytoplasm of a chromatolytic nerve cell still contains many fine granules, though the large Nissl bodies have disappeared. Wiemann reported the same observation with ultraviolet light microscopy. It is impossible to tell, however, whether these fine granules represent degradation products of the Nissl bodies or substance of an entirely different chemical nature. According to Gersh and Bodian ('43) depolymerization of RNA in the Nissl bodies by ribonuclease or similar enzymes in the neuron may account for the breaking up of these bodies with consequent increase of cytoplasmic osmotic pressure resulting in an uptake of water causing cellular swelling, eccentric position of the nucleus, and other changes in chromatolysis. However, in the present study we have shown that though ribonuclease promptly removed basophilia of the Nissl bodies in the isolated neuron, no apparent alteration in the structure of these bodies took place. Possibly, additional factors besides RNA depolymerization may be necessary to start the chain of events leading to chromatolysis.

The lipochrome pigment in the nerve cell has been studied by many earlier neuroanatomists. Our findings concerning the time of appearance of this pigment in the anterior horn cells are in agreement with those of Pilez (1895) and Obersteiner ('03, '04) who found that the pigment first appeared in the spinal ganglion cells at the 6th year, in the spinal cord about two years later, and still later in the cerebral cortex. The lipoid nature of this pigment has long been known on account of its stainability by certain fat stains. Recently, attention has been called to its acid-fast property (Wolf and Pappenheimer, '45) and the presence of a carbohydrate component in its make-up (Dixon and Herbertson, '50). Because 
of its early appearance in life, this pigment has been considered as a product of activity rather than of senescence. If it is a metabolic product peculiar to certain nerve cells, an accurate knowledge of its chemical composition may throw some light on the metabolism of the neuron. This will depend on successful isolation of this pigment in sufficient amounts for chemical analysis.

It is well known that marked difference in structure exists between dendrites and axons. One constant feature about the dendrites is the presence of granulations on their surface. In cultures of nervous tissue, the cytoplasmic granules in the neurites have also been observed to have the tendency to migrate toward the edge (Costero and Pomerat, '50). We have interpreted the occurrence of excrescences on the dendrites of the anterior horn cells from certain individuals to represent an exaggeration of this surface granulation. Another possibility is that the excrescences are the detached boutons of the axons of other neurons terminating on the neuron in question. However, in our material, nerve cells which show numerous excrescences over their dendrites rarely show similar structures on the cell-body. One would expect boutons terminating on the cell-body just as numerous as those ending on the dendrites.

Unlike the dendrites, the axon has an entirely different structure. Not only are the coarser granules entirely absent but also the fine granules in the axon seem to be arranged in rows along the longitudinal axis of the axon. These fine granules are probably mitochondria. Their arrangement in rows in the axon were described before by Held (neurosomes) in stained sections. We are, however, unable to demonstrate the presence of a mesh-work (axospongium) in the axoplasm by phase microscopy. As some other observers have found, no definite structure is discernible in the fresh axon by ordinary light and darkfield microscopy (Auerbach, '29; Ettisch and Jochims, '26; de Rényi, '29).

The constriction of the axon just before it acquires the myelin sheath is of special interest. We believe that this is 
a constant feature in all anterior horn cells. Strong and Elwyn ('48) have presented the photograph of a section of an infant's spinal cord showing the same phenomenon in one of the spinal motor cells. Ramón y Cajal ('11) has called attention to a similar constriction in the axon of the Purkinje cells of the cerebellum. Whether this constriction in the initial segment of the axon occurs also in other neurons remains to be demonstrated. It has been suggested that the narrowing in the diameter of the axon in this region may constitute an anatomical basis for the axon-soma block of nerve impulses under certain physiological conditions (Chang, '52). That the occurrence of other constrictions further in the course of the axon inside the spinal cord is probably related to the presence of the nodes of Ranvier in the central nervous system has been alluded to above.

\section{SUMMARY}

A method has been described for the isolation of nerve cells from the anterior gray column of the spinal cord of man by shaking the gray matter in a physiological salt solution to free the cells from the supportive elements and then separating them by differential flotation. The structure of these isolated anterior horn cells has been studied by conventional and phase microscopy and with the aid of certain stains and chemicals.

The cytoplasm of the nerve cell consists of a homogeneous ground substance of high viscosity, suspended in which are numerous granules (Nissl bodies, mitochondria, lipochrome pigment, etc.). Neurofibrils and Golgi bodies have not been observed in the present study.

The Nissl bodies are not clearly visible under ordinary light microscope but are demonstrable by phase microscopy. They have strong affinity for basic dyes, but the basophilic property is lost upon storage. Incubation with ribonuclease promptly removes the basophilic property, but Nissl bodies show no remarkable change in appearance after the loss of basophilia. Frankly chromatolytic neurons were occasionally 
isolated from certain individuals. However, it has not been possible to produce the phenomenon of chromatolysis on neurons which have normal Nissl bodies at the time of isolation.

Lipochrome pigment is absent from the nerve cells of the new-born, begins to appear early in life (at about the 6th year), and increases in amount with advancing age. The pigment granules are resistant to certain chemicals which readily destroy the neuroplasm.

The dendrites have surface granulations which may occur in aggregates to give the appearance of excrescences in the nerve cells from certain individuals. The axon has a smooth surface, but the axoplasm also contains many fine granules which are arranged in rows but not evenly distributed. The axon shows a distinct narrowing in diameter before it enters the myelin sheath and has constrictions at intervals, presumably corresponding to the nodes of Ranvier believed to be present in the central nervous system.

The nucleus is vesicular, containing a large nucleolus. There is a well-defined nuclear membrane, though in the fresh nerve cell its visibility is often obscured by the densely packed cytoplasmic granules.

It is suggested that for other than cytological studies, these isolated nerve cells may furnish suitable material for the study of the physical properties and the chemical composition of the neuron, the reactions of the neuroplasm to various chemical and biological agents, and possibly the metabolism of the isolated neuron.

\section{ACKNOWLEDGMENT}

The author wishes to express his thanks to Dr. Thomas Francis, Jr., for introduction to the present study and continued interest in its progress, to Dr. Carl V. Weller and Dr. A. James French for the supply of autopsy material, and to Dr. Elizabeth Crosby for help in the preparation of the manuscript. 


\section{LITERATURE CITED}

Allison, A. C., AND W. H. Feindel 1949 Nodes in the central nervous system. Nature, 163 : 449-450.

A UERBACH, L. 1929 Ultramikroskopische Befunde am Ischiadicus des Frosches (Norm, Einwirkung von Elektrolyten, Narkose) in ihrem Verhältnis zu den Feststellungen am fixierten Präparate. Pflüger's Arch. ges. Physiol., 2.22: 493-509.

Beams, H. W., V. L. van Breemen, D. M. Newfang and T. C. Evans 1952 A correlated study on spinal ganglion cells and associated nerve fibers with the light and electron microscopes. J. Comp. Neur., $96 ; 249$ 281.

BEAMS, H. W., AND R. L. KING 1935 The effect of ultracentrifuging the spinal ganglion cells of the rat, with special reference to Nissl bodies. J. Comp. Neur, 61: 175-189.

Bensley, R. R., AND I. Gersh 1933 Studies on cell structure by the freezingdrying method. III. The distribution in cells of the basophil substances in particular the Nissl substance of the nerve cell. Anat. Rec., 5\%: 369-385.

Bodian, D. 1950 A note on nodes of Ranvier in the central nervous system. J. Comp. Neur., 94: 475-483.

Brachet, J. 1940 La détection histachimique des acides pentose nucleiques. Compt. rend. soc. biol., 133: 88-90.

CHANG, H. T. 1952 Cortical neurons with particular reference to the apical dendrites. Cold Spring Harbor Symposia, Quant. Biol., 17: 189-202.

ChINN, P. 1935 Polarization optical studies of the structure of nerve cells. J. Cell. and Comp. Physiol, 12: 1-22.

Costero, I., AND C. M. Pomerat 1951 Cultivation of neurons from the adult human cerebral and cerebellar cortex. Am. J. Anat., 89: 405-468.

Davidson, J. N. 1947 The distribution of nucleic acids in tissues. Symposja Soc. Exp. Biol., 1: 77-85.

Dixon, K. C., AND B. M. Herbertson 1950 Clusters of granules in human neurones. J. Path. and Bact., 62: 335-339.

Finarson, L. 1935 Histological analysis of the Nissl-pattern and substance of nerve cells. J. Comp. Neur., 61: 101-127.

EтTाSCh, G., AND J. Jochims 1926 Dunkelfeld Untersuchungen am überlebenden Nerven. I. Mitteilung. Die Wirkung von Elektrolyten. Pflüger's Arch. ges. Physiol., 215: 519-544.

Frrnandez-Moran, H. 1952 The submicroseopic organization of vertebrate nerve fibers. An electron microscope study of myelinated and unmyelinated nexve fibers. Exp. Cell Res., 3: 282-359.

GERSH, I., AND D. BoDIAN 1943 Some chemical mechanisms in chromatolysis. J. Cell. and Comp. Physiol., 21: 253-279.

HANKS, $J$. H., AND R. E. WALLACE 1949 Relation of oxygen and temperature in the preservation of tissues by refrigeration. Proc. Soc. Exp. Biol. and Med., 71: 196-200.

HELd, H. 1895 Beiträge zur Structur der Nervenzellen und ihrer Fortsätze. Erste Abhandlung. Arch. f. Anat. u. Physiol. (Anat, Abt.), 396-416. 
HeLD, H. 1897 Beiträge zur Struktur der Nervenzellen und ihrer Fortsätze. Zweite Abhandlung. Areh. f. Anat. u. Physiol. (Anat. Abt.), 204294.

Hess, A., ANd J. Z. Young 1949 Nodes of Ranvier in the central nervous system. J. Physiol., 108: 52.

Hogue, M. J. 1947 Human fetal brain cells in tissue cultures: their identification and motility. J. Exp. Zool., 106: 85-107.

1950 Brain cells from human fetuses and infants cultured in vitro after death of the individuals. Anat. Rec., 108: 457-475.

Hydes, H. 1947 Protein and nucleotide metabolism in the nerve cell under different functional conditions. Symposia Soc. Exp. Biol., 1: 152-162.

KLein, E., N. B. KuRNick and G. KleiN 1950 The effect of storage on the nucleic acid content and virulence of mouse ascites tumor. Exp. Cell Res., 1. 127-134.

KraUS, W. M., AND A. WEIL 1926 Human adult and embryo anterior horn cells. Arch. Neur, and Psychiat., 15: 686-701.

Marinesco, G, 1911 Etudes ultramicroscopique des cellules des ganglions spinaux des animaux nouveau-nes. Compt. rend. soc. biol., 70: 1057-1060.

MoтT, F. M. 1912 Discussion on the biophysies and biochemistry of the neurone. Brit. M. J., 2: $780-784$.

DE Moulin, F. 1923 Beiträge zur Kenntnis des Baues der Ganglienzellen. Arch. f. Zellforsch., $17:$ 389-396.

Murray, M. R., AND A. P. Stout 1947 Adult human sympathetie ganglion cells cultivated in vitro. Am. J. Anat, 80: 225-273.

Obersteiner, H. 1903 Über das hellgelbe Pigment in den Nervenzellen und das Vorkommen weiterer fettähnlicher Körper im Centralnervensystem. Arb. a. d. Neur. Inst. a. d. Wien Univ., 10: 245-273.

1904 Weitere Bemerkungen über die Fett-Pigmentkörnchen im Centralnervensystem. Arb. a. d. Neur. Inst. a. d. Wien Univ., 11: 400406.

Pilcz, A. 1895 Beiträg zur Lehre von der Pigmententwickelung in den Nervenzellen. Arb. a. d. Neur. Inst. a. d. Wien Univ., 3: 123-139.

Pomerat, C. M., J. R. Ewalt, S. R. Snodgrass and M. F. OrR 1950 Tissue cultures of adult human cortex. Texas Rep. Biol. and Med., $s$ : 108110.

RALPF, P. H. 1952 Demonstration of some structures from the nervous system of the rat with the light microscope (abstract). Anat. Rec., 118: 378.

RAmón y CAJaL, S. 1911 Histologie du système nerveux de l'homme et des vertébrés. Tome II. A. Maloine, Paris, p. 12.

DE RÉnyi, G. ST. 1929 Structure of cells in tissues as revealed by microdissection. II. The physical properties of the living axis cylinder in myelinated fiber of the frog. J. Comp. Neur., 47: 405-425.

1931 Structure of cells in tissues as revealed by microdissection. V. The physical properties of nerve cells of the frog (Rana pipiens).

J. Comp. Neur., 53: 497-509. 
DE RfNYI, G. ST. 1932 Architecture of the nerve cell as revealed by microdissection. Special Cytology. Ed. by E. V. Cowdry. Hoeber, New York, vol. 3: 1371-1402.

StMms, H. S., AND M. SANDERS 1942 Use of serum ultrafiltrate in tissue cultures for studying deposition of fat and for propagation of viruses. Arch. Path., 33 : 619-635.

Strone, O. S., ANd A. EuWYN 1948 Human Neuroanatomy. 2nd Ed. Williams and Wilkins, Baltimore, p. 32.

UnNa, P. G., and O. Gans 1914 Zur Chemie der Zelle, IV. Die Nisslkörper. Berl. klin. Wochenschr., 51 : 444-448.

Wiemans, W. 1925 Studien am Zentralnervensystem des Menschen mit der Mikrophotographie im ultravioletten Licht. Zeitschr. ges. Neur. and Psychiat., 98: 347-404.

Wolf, A., ANd A. M. Pappen heimer 1945 Oceurrence and distribution of aeidfast pigment in the central nervous system. J. Neuropath. and Exp. Neur., 4: 402-406. 
PLATE 1,

EXPLANATTON OF FIGURES

Anterior horn cells isolated from individuals of different ages.

1 An anterior horn cell from a three-year old child. Note the absence of lipoehrome pigment. $\times 290$.

2 An anterior horn cell from an 18-year old man. A moderate amount of lipochrome pigment inside the cell. $\times 290$.

3 An anterior horn cell from a 56-year old man. Note a much larger amount of lipochrome pigment. $\times 290$.

4 A higher magnification of the cell in figure 3 . The nucleus has a prominent nucleolus and a distinct membrane. Nissl bodies are not visible. $\times 620$. 

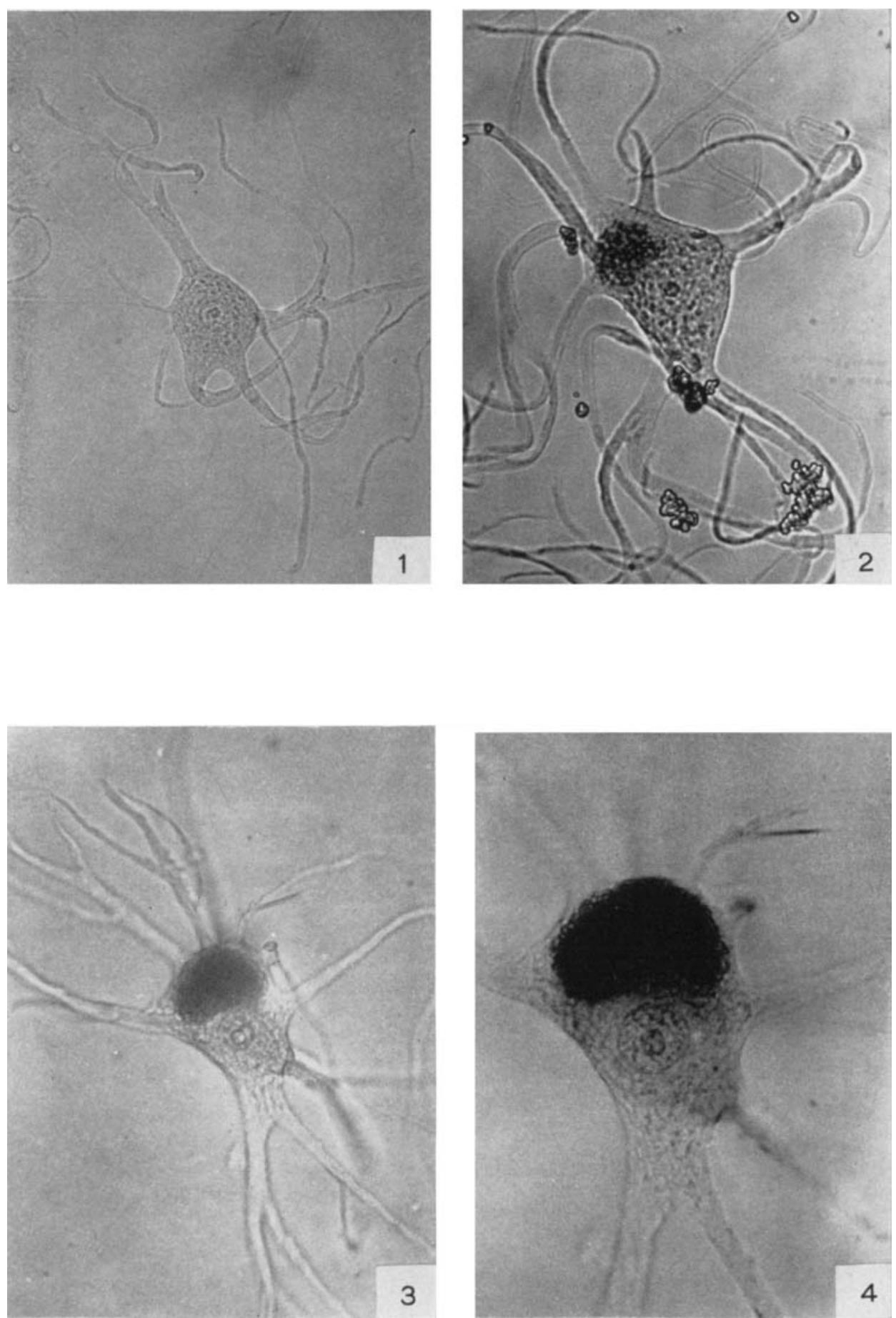


\section{PLATE 2}

\section{EXPLANATION OF FIGURES}

Anterior horn cells of a new-born infant.

5 A spinal neuron isolated from a new-born. Note the number and length of the dendritic processes. $\times 340$.

6 A spinal neuron from a new-born. Both nucleus and Nissl bodies ean be fairly well seen. $\times 620$.

3 Phase microscope view of an infant anterior horn cell. The Nissl bodies are clearly visible. $\times 620$. 

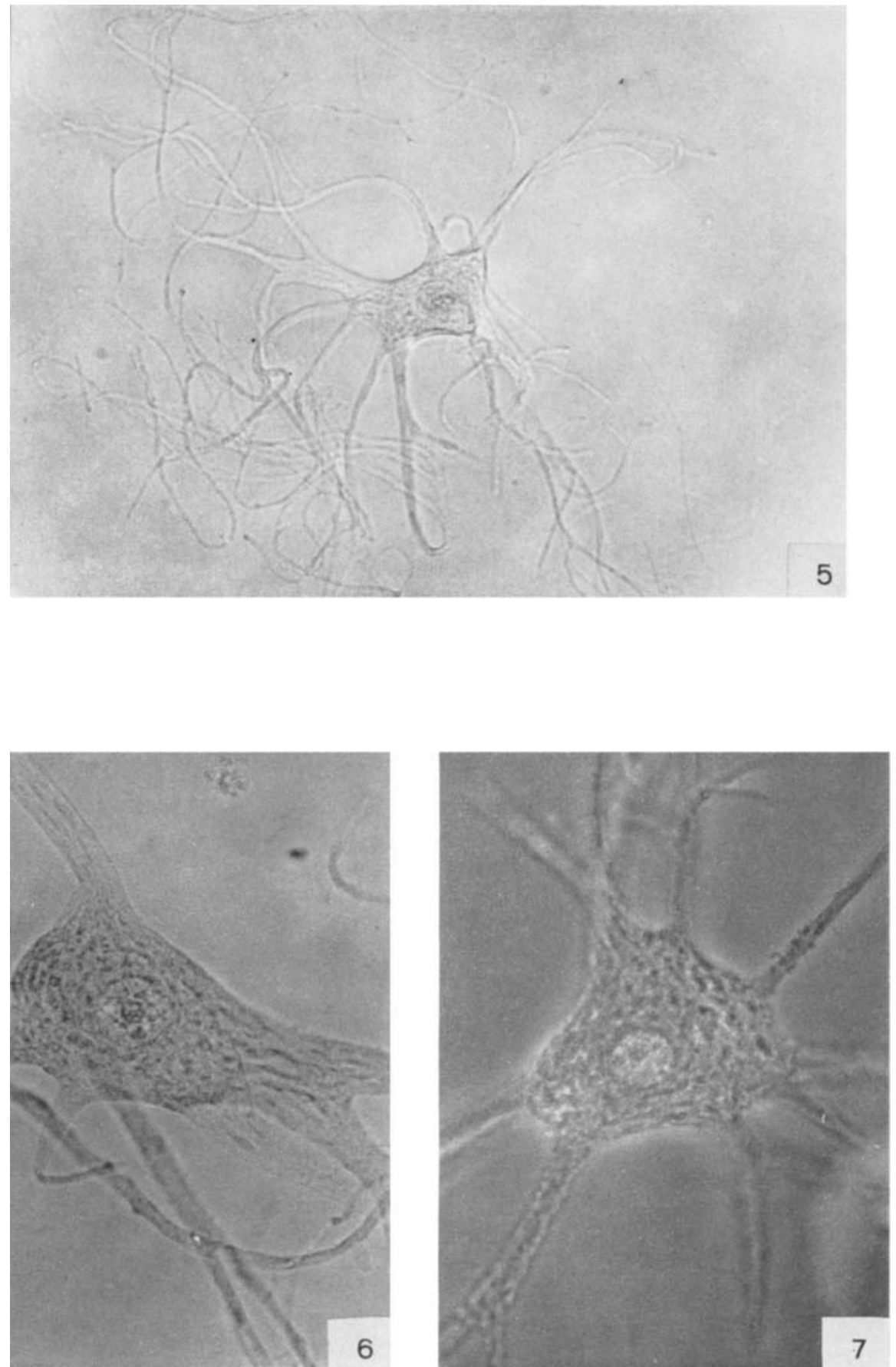


\section{PLATE 3}

\section{EXPLANATION OF FIGTJRF}

$8,9,10,11$ Small nerve cells isolated from the spinal cord of adult men. They are different from the spinal motor neurons in both size and shape. Some lipochrome pigment is also found in the cytoplasm. $\times 240$. 

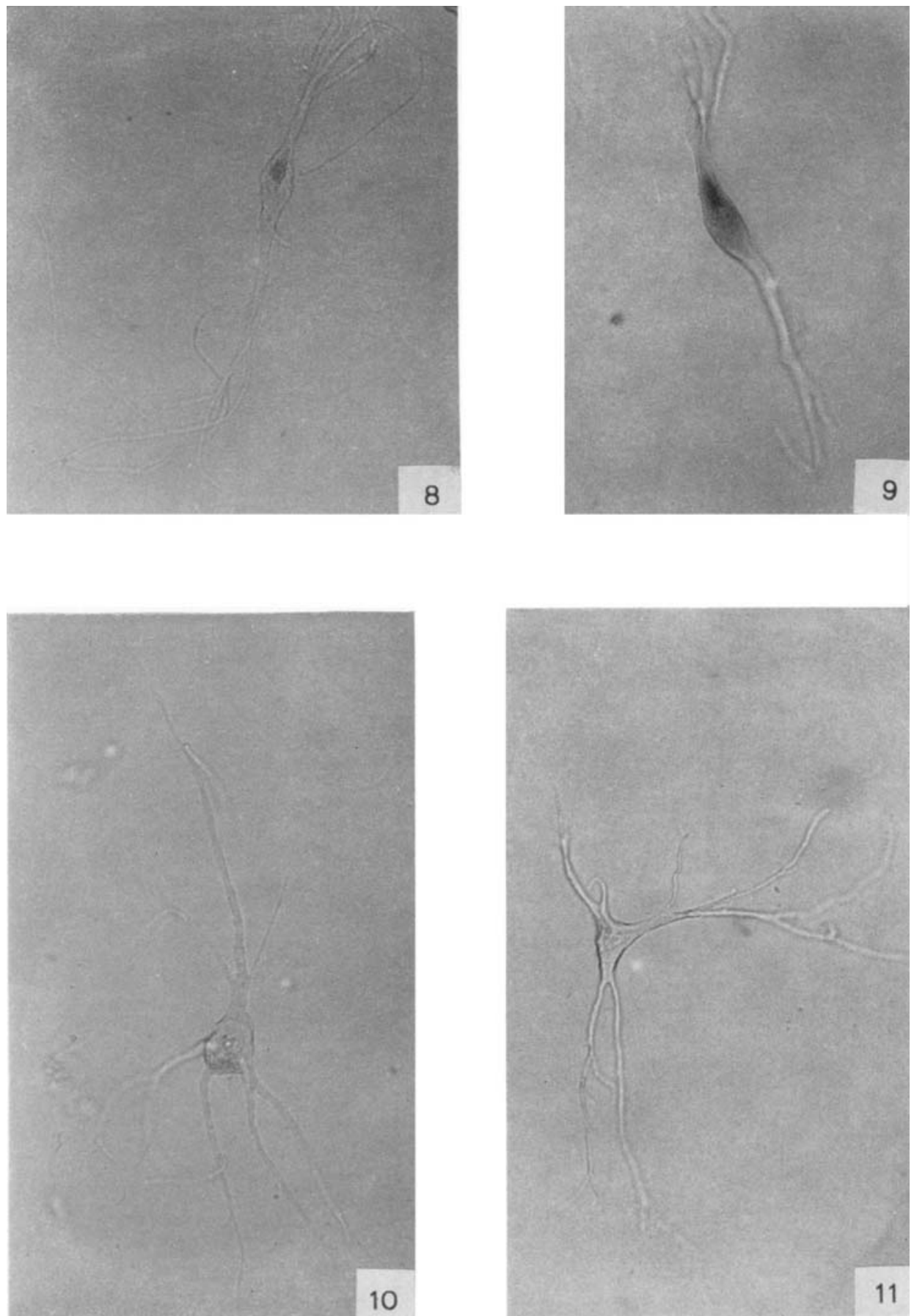
PLATE 4

EXPLANATION OF FIGLTRES

Comparison of normal and ehromatolytie anterior horn eells.

12 A normal anterior horn cell from a 60-year old man, stained with 1:10,000 metlylene blue. Note well-defined Nissl bodies. $\times 620$.

13 Another cell from the same individual viewed under phase microscope. Nissl bodies are well demonstrated. $\times 620$.

14 A cluromatolytic anterior horn cell from a 62-year old man, stained with 1: 10,000 methylene blue. Note markedly swollen cell-body, complete absence of Nissl bodies, and eccentric position of the nucleus. $\times 620$.

15 Another chromatolytic neuron from the same man, under phase microseope. Cell-body swollen, cytoplasm filled with fine granules, but no Nissl bodies. $\times 620$. 

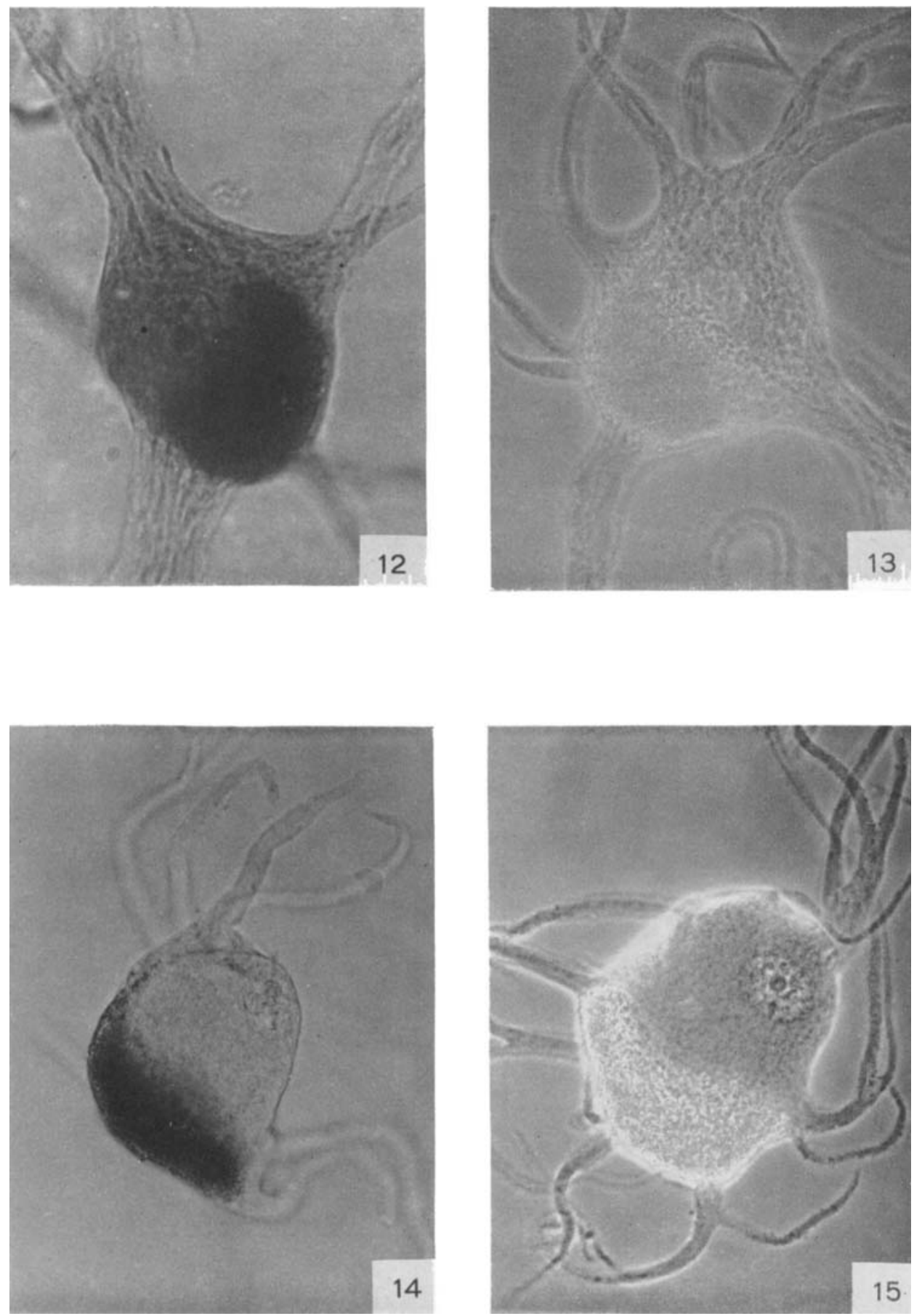


\section{PLATE 5}

\section{EXPLANATION OF FIGURES}

16 "Excrescences" on the surface of a large dendrite trunk. $\times 1150$. Phase.

17 Small dendritic branches showing surface granulation. $\times 1150$. Phase.

18 An anterior horn cell from a 48-year old man, showing a large number of "excrescences" on the surface of the dendrites. $\times 520$.

19 Free lipochrome pigment granules after the eytoplasm of the nerve cell was dissolved by $\mathrm{N} \mathrm{NaOH} . \times 620$. 

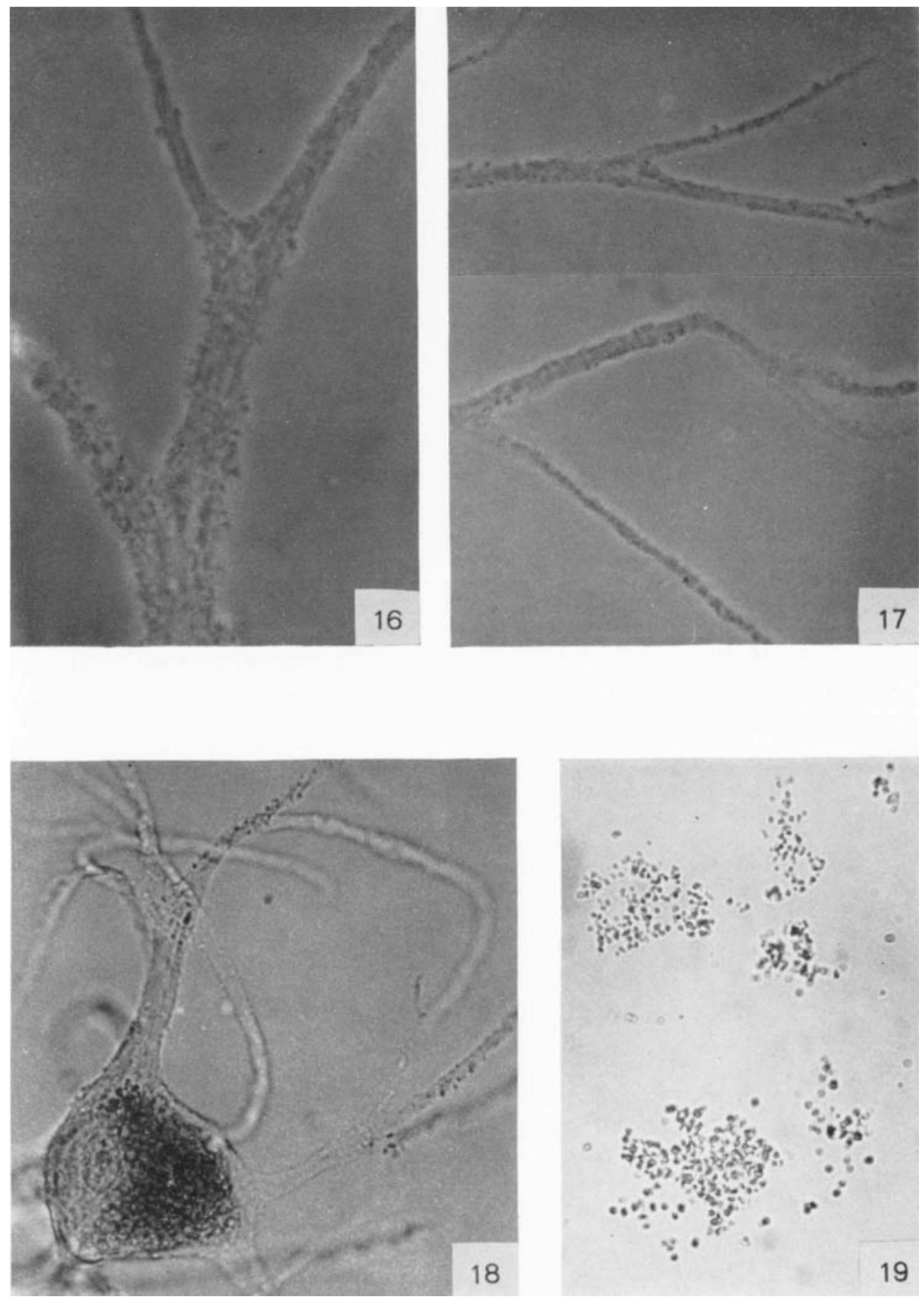
PLATE 6

EXPLANATION OF FIGURES

Infant and adult anterior horn cells showing a constriction in the diameter of the axon shortly after its emergence from the cell-body.

20 An anterior horn cell from a new-born infant. Shortly after leaving the cell-body, the axom tapers into a thin thread (arrow) and then gradually expands again to form an axis eylinder of fairly uniform diameter. $\times 340$.

21 An anterior horn cell from a 53-year old man, showing a distinct eonstriction in the initial segment of the axon (arrow). $\times 240$.

22 Another anterior horn cell from the same individual, showing a narrowing in the diameter of the axon (arrow) immediatcly before it enters the myelin sheath. $\times 520$. 

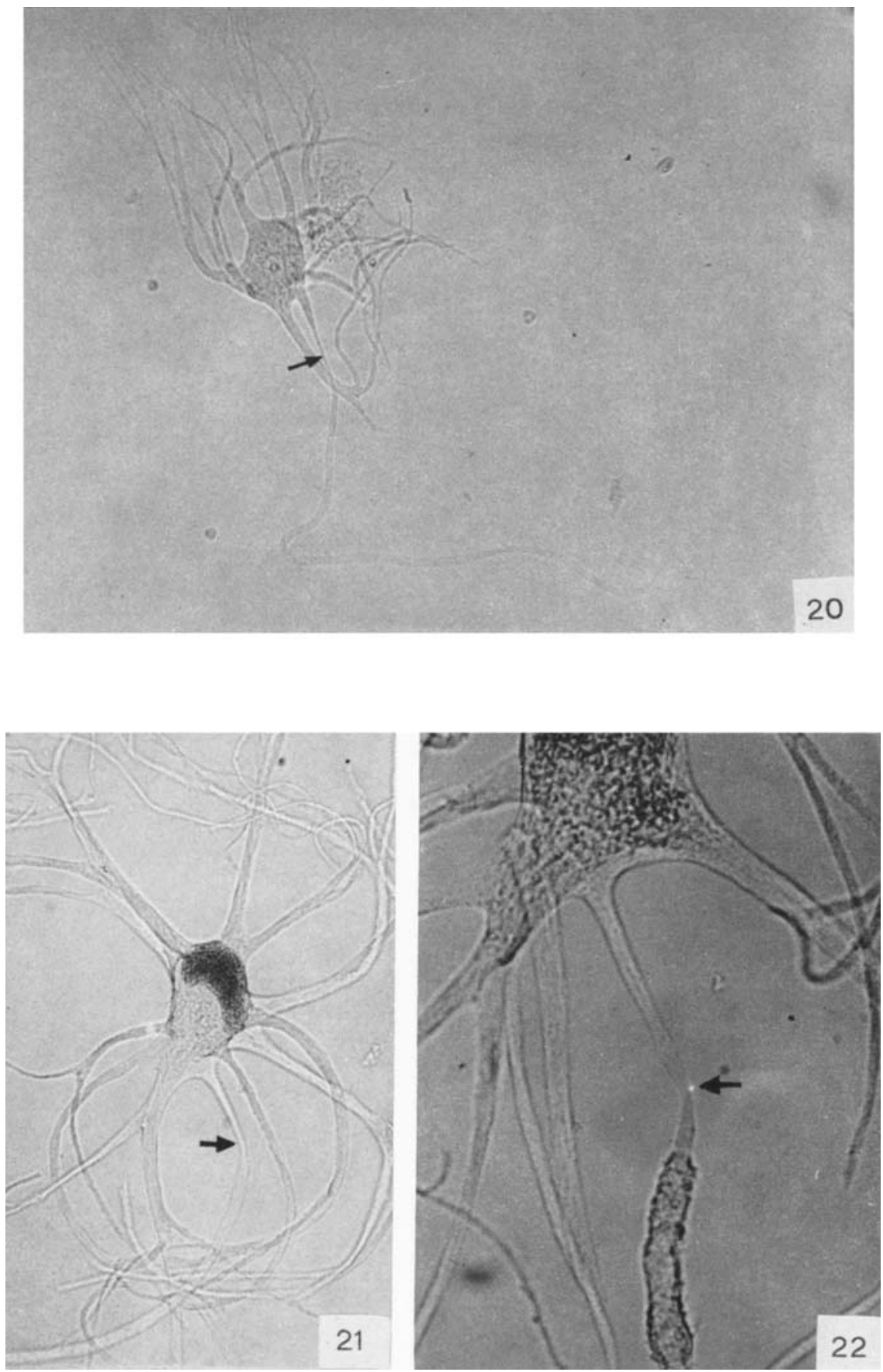
PLATE 7

EXPLANATION OF FIGURES

23 A segment of myelin sheath with a bare axis cylinder protruding from one end. Note bulgings of the myelin sheath. $\times 240$.

24 "Nodal constriction" of a naked axon. The myelin sheath is believed to become detached from the axon during cell separation processes. $\times 620$. Phase.

25 A highly magnified view of a segment of a naked axon. Note the presence of granules and rodlets in the axoplasm. $\times 1360$. Phase.

26 A protoplasmic astrocyte. $\times 520$. Phase.

27,28 Oligodendroglias. $\times 620$. Phase. 

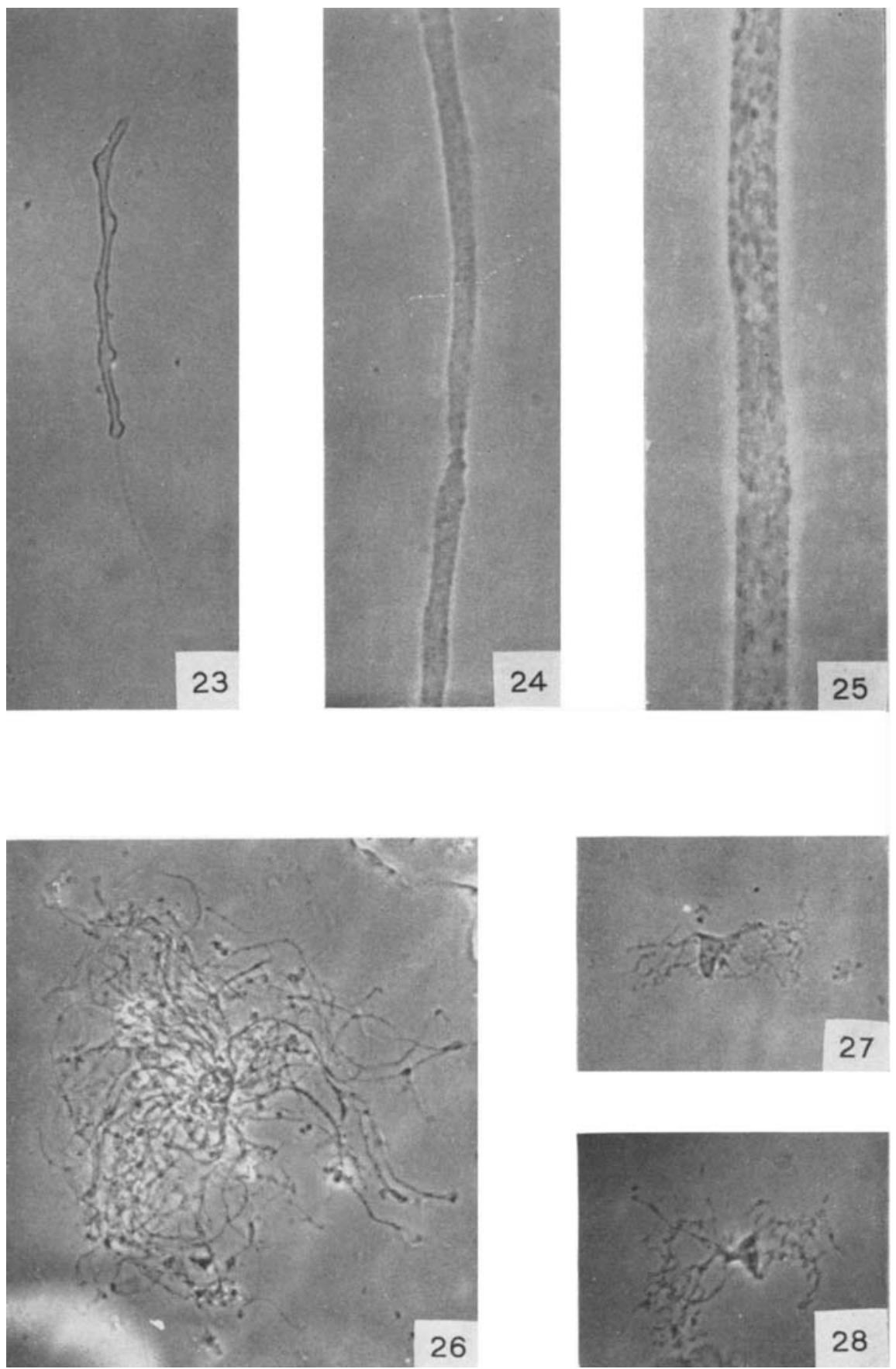